\title{
Effects of Ethylsalicylic Acid on Growth and Rubisco/Rubisco Activase in Tobacco Plant Cultured under Cadmium Treatment in vitro
}

\author{
Kwang Soo Roh* and Qiu Jie Cui \\ Department of Biology, Keimyung University, Daegu 704701, Korea \\ Received February 6, 2014 /Revised April 3, 2014 /Accepted May 7, 2014
}

\begin{abstract}
Growth induced by cadmium (Cd) and ethylsalicylic acid (ESA) and the effect of ESA on rubisco/rubisco activase were studied in tobacco. The effect of denaturants on rubisco/rubisco activase was also investigated. In order to determine optimal concentration of ESA for growth of tobacco, tobacco was treated with $10^{-6}-10 \mathrm{mM}$. It was found that its growth was the highest at $10^{-4} \mathrm{mM}$ ESA. In the experiment using control, $\mathrm{Cd}$ treated group, ESA treated group, and Cd and ESA mixture group, ESA alone showed the highest growth and $\mathrm{Cd}$ showed the lowest growth. $\mathrm{Cd}$ treated group was the lowest in both rubisco/rubisco activase content and activity. ESA reduced the rubisco/rubisco activase content, but increased their activity. The activity of rubisco was inhibited by treating L-cysteine, urea, thiourea, $\beta$-mercaptoethanol, and EDTA other than guanidine- $\mathrm{HCl}$ in control group. L-cysteine, urea, thiourea, and guanidine- $\mathrm{HCl}$ treatments showed no change, but $\beta$-mercaptoethanol and EDTA increased rubisco activase activity. In conclusion, ESA inhibited the content of rubisco and promoted its activity, whereas promoted the content of rubisco activase and inhibited its activity. In addition, the content and activity of rubisco and rubisco activase inhibited by $\mathrm{Cd}$ were recovered by ESA. The activity of rubisco and rubisco activase by Cd and ESA was inhibited by the denaturant and the recovery of ESA inhibited by $\mathrm{Cd}$ was lost by the denaturant.
\end{abstract}

Key words : Cadmium, denaturant, ethylsalicylic acid, rubisco, rubisco activase, tobacco

\section{Introduction}

Rubisco (ribulose 1,5-bisphosphate carboxylase/oxygenase) is an enzyme involving a reaction generating PGA (phosphoglycerate) from RuBP (ribulose 1,5-bisphosphate) and $\mathrm{CO}_{2}$ a carbon fixation during dark reaction of photosynthesis [3]. Rubisco, which is the most abundant protein in plant, is located in stroma and accounts for about $15 \%$ of total chloroplast protein [8]. Rubisco has $560 \mathrm{kDa}$ of molecular weight and consists of 8 large subunits with $55 \mathrm{kDa}$ of molecular weight and 8 small subunits with $15 \mathrm{kDa}$ of molecular weight. The large subunits are encoded from chloroplast genes and the small subunits are encoded from nuclear genes and then they are assembled in the chloroplast after protein synthesis [26].

Rubisco activase acts as a chaperone to control the activity of rubisco [16]. This enzyme keeps rubisco to be highly ac-

\footnotetext{
*Corresponding author

Tel : +82-53-580-5207, Fax : +82-53-580-5164

E-mail : rks@kmu.ac.kr

This is an Open-Access article distributed under the terms of the Creative Commons Attribution Non-Commercial License (http://creativecommons.org/licenses/by-nc/3.0) which permits unrestricted non-commercial use, distribution, and reproduction in any medium, provided the original work is properly cited
}

tive in vivo and has activity of ATPase [12] and controlled by rubisco activase under presence of RuBP and ATP [21, 34]. In addition, the rubisco activase plays a role in dissociating several kinds of sugar phosphate bound to active region of rubisco [9].

The heavy metal cadmium (Cd) is one of the major environmental contaminants [17]. When present at elevated levels in water and soil it is readily absorbed by root systems and accumulated mainly in the vacuoles to higher concentration, thereby inducing reduced growth and impaired metabolism in plants [29]. Cd delays development and differentiation in plant and is known as a substance disturbing metabolism of nucleic acids and proteins as well as photosynthesis, photorespiration, and nitrogen metabolism [24].

Ethylsalicylic acid (ESA) is a chemically synthesized derivative of salicylic acid (SA) [23] which alleviates the heavy metal ion toxicity, and has antibiotic activity [6]. ESA has $166 \mathrm{Da}$ of molecular weight and is a colorless fluid, which changes to yellow under light [13]. Although ESA can be mixed with ethanol and ether, it is not a material synthesized naturally in plant and that can be synthesized chemically by reaction with ethanol. Poly [bis (ethyl salicylate) phosphazenes] and poly [bis (ethyl salicylate diethylamino) phosphazenes] synthesized from ESA are not only applied 
to biocompatibility, soft tissue artificial organ, chemical therapy model and drug delivery system in biomedical area, but also classified into degradable material due to their characteristics $[1,2]$.

Like these, although reports on ESA synthesis and its derivatives and antibacterial action for ESA have been known [6], there is no report on plant growth, rubisco, and rubisco activase by ESA in tobacco. In previous study, we determined that influence of SA on $\mathrm{Cd}$ induced rubisco/rubisco activase, and effect of denaturants on its activity in tobacco grown in vitro were studied [30]. Therefore in this study, an effect of ESA on Cd was studied by identifying the effect of ESA on growth of tobacco and rubisco/rubisco activase and effects of denaturants on its activity.

\section{Materials and Methods}

\section{Apparatus and chemicals}

Refrigerator centrifuge (Kontron T-324, Korea), fraction collector (Bio-Rad 2110, CA, USA), UV-VIS spectrophotometer (GeneQuant 100, GE Heal thcare, England), and ELISA microplate reader (Bio-Rad 680, CA, USA) were used in our study. All chemicals were obtained from SigmaAldrich (St. Louis, MO, USA) unless noted otherwise.

\section{Tobacco culture and growth}

Tobacco (Nicotiana tabacum L.) seeds sterilized in 70\% (v/v) ethanol and $3 \%(v / v)$ sodium hypochlorite solution were germinated and grown aseptically in MS agar medium [14]. Four week-old shoots were cut into $3 \mathrm{~cm}$ segments for use as explants. For determination of optimal concentration of ESA, three explants were placed on an induction MS medium of $10^{-6} \mathrm{mM}$ - $10 \mathrm{mM}$ ESA concentrations, respectively and then cultured for 10 weeks. For measurement of effect of ESA and Cd on growth, rubisco and rubisco activase, explants were cultured in MS medium of control (without $\mathrm{Cd}$ and ESA), $10^{-4} \mathrm{mM}$ ESA, Cd $\left(0.2 \mathrm{mM} \mathrm{CdCl} 2 \cdot 2.5 \mathrm{H}_{2} \mathrm{O}\right)$, ESA $+\mathrm{Cd}$ for 12 weeks at $26 \pm 1^{\circ} \mathrm{C}$ under a 16-h light $(800 \mu$ $\mathrm{M} / \mathrm{m}^{2} / \mathrm{s}$ PFD) and 8 -h dark photoperiod [20]. Fully expanded leaves from mature plants were used for experiments. All experiments were independently triplicated.

\section{Isolation of rubisco and rubisco activase}

Isolation of rubisco and rubisco activase from tobacco leaves was used the methods from Wang et al. [31]. Frozen leaf tissue was grounded in the extraction buffer containing
$50 \mathrm{mM}$ BTP (pH 7.0), $10 \mathrm{mM} \mathrm{NaHCO}, 10 \mathrm{mM} \mathrm{MgCl}_{2}, 1$ mM EDTA, $0.5 \mathrm{mM}$ ATP, $10 \mathrm{mM}$ DTT, $1 \mathrm{mM}$ PMSF, $1 \mathrm{mM}$ benzamidine, $0.01 \mathrm{mM}$ leupeptin, 1.5\% PVPP, and $3 \mathrm{mM}$ MBT. The leaf slurry was filtered through four layers of cheesecloth and one layer of Miracloth. Filtered solution was centrifuged at 30,000x $g$ for $40 \mathrm{~min}$. Ammonium sulfate powder was slowly added into the supernatant to $35 \%$ saturation stirring for $30 \mathrm{~min}$. The supernatant containing rubisco and pellet containing rubisco activase were collected by centrifugation at $8,000 \mathrm{x} g$ for $10 \mathrm{~min}$, respectively. The supernatant collected was brought to $55 \%$ saturation of ammonium sulfate by addition of powder. The pellect collected by centrifugation at $8,000 \mathrm{x} g$ for $10 \mathrm{~min}$ was resuspended in $20 \mathrm{mM}$ BTP ( $\mathrm{pH} \mathrm{7.0)}$ containing $0.2 \mathrm{mM} \mathrm{ATP}, 10 \mathrm{mM}$ $\mathrm{MgCl}_{2}$ and $2 \mathrm{mM} \mathrm{MBT} \mathrm{(buffer} \mathrm{A),} \mathrm{and} \mathrm{50 \%} \mathrm{PEG-10K} \mathrm{was}$ added to a final concentration of $18 \%$. The precipitate was collected by centrifugation at $8,000 \times g$ for $10 \mathrm{~min}$. Resuspended solution in buffer A was applied to a Q-Sepharose column equilibrated with $20 \mathrm{mM}$ Tris ( $\mathrm{pH}$ 7.5), $10 \mathrm{mM} \mathrm{MgCl}$, and $10 \mathrm{mM} \mathrm{NaHCO}$. The column washed with the same buffer containing $0.1 \mathrm{M} \mathrm{NaCl}$ was eluted with a linear gradient from 0.1 to $0.5 \mathrm{M} \mathrm{NaCl}$ at a flow rate of $1.5 \mathrm{ml} / \mathrm{min}$. $3 \mathrm{ml}$ fractions were pooled to provide for assay of rubisco content and activity.

$50 \%(\mathrm{w} / \mathrm{v})$ PEG-10K was added into the buffer A resuspended pellet obtained above to the final concentration to $18 \%$, stirred $5 \mathrm{~min}$, and centrifuged at $8,000 \times g$ for 10 $\min$. The pellet was dissovled in buffer A. Solution was cleared by spinning at 20,000x $g$ for $10 \mathrm{~min}$. Pellet was resuspended again in buffer. The collected supernatants were applied to a Q-Sepharose column equilibrated with $20 \mathrm{mM}$ BTP (pH 7.0). The column washed with $20 \mathrm{mM}$ BTP (pH 7.0) was eluted with a linear gradient from 0 to $0.5 \mathrm{M} \mathrm{NaCl}$ in $20 \mathrm{mM}$ BTP (pH 7.0) at a flow rate of $1 \mathrm{ml} / \mathrm{min} .3 \mathrm{ml}$ fractions were pooled to provide for assay of rubisco activase content and activity. All processing were done at $4^{\circ} \mathrm{C}$ except as indicated.

\section{Measurement of content and activity of rubisco}

Rubisco content was determined at $280 \mathrm{~nm}$ spectrophotometrically, and calculated by the following equation [32]: Content $(\mathrm{mg} / \mathrm{ml})=\mathrm{A}_{280} \times 0.61$. Rubisco activity was determined spectrophotometrically by NADH oxidation at 340 $\mathrm{nm}$ [18]. The reaction mixture contained $1 \mathrm{M}$ Tris buffer $(\mathrm{pH}$ 7.8), $0.006 \mathrm{M} \mathrm{NADH}, 0.1 \mathrm{M} \mathrm{GSH}, 0.5 \%$ glyceraldehyde3-phosphate dehydrogenase, $0.025 \mathrm{M}$ 3-phosphoglycerate 
kinase, $\quad 0.05 \%$ a-glycerophosphate dehydrogenase-triose phosphate isomerase, $0.025 \mathrm{M}$ RuBP, $0.2 \mathrm{M}$ ATP, $0.5 \mathrm{M}$ $\mathrm{MgCl}_{2}, 0.5 \mathrm{M} \mathrm{KHCO}_{3}$, and isolated rubisco solution. One unit of enzyme was defined as the amount of enzyme producing $1 \mu \mathrm{M}$ of RuBP per min.

\section{Measurement of content and activity of rubisco activase}

Rubisco activase content was determined at $595 \mathrm{~nm}$ by the method of Bradford [4] using bovine serum albumin as a standard. Rubisco activase activity was determined as the ability to produce ADP at $340 \mathrm{~nm}$ [19]. The isolated rubisco activase solution was added to the activation reaction mixture containing $50 \mathrm{mM}$ Tricine ( $\mathrm{pH} 8.0), 20 \mathrm{mM} \mathrm{KCl}, 10 \mathrm{mM}$ $\mathrm{MgCl}_{2}, 1 \mathrm{mM}$ ATP, $1 \mathrm{mM}$ phosphoenolpyruvate, $0.3 \mathrm{mM}$ $\mathrm{NADH}, 40$ units $/ \mathrm{ml}$ pyruvate kinase, and 40 units $/ \mathrm{ml}$ lactate dehydrogenase. One unit was defined as the amount that catalyzed the cleavage of $1 \mu \mathrm{M}$ ATP per min.

\section{Measurement of activity of rubisco and rubisco activase by denaturants}

$10 \mathrm{mM}$ L-cysteine, $10 \mathrm{mM} \beta$-mercaptoethanol, $10 \mathrm{mM}$ EDTA, $10 \mathrm{mM}$ urea, $10 \mathrm{mM}$ thiourea, and $10 \mathrm{mM}$ guanidine- $\mathrm{HCl}$ as denaturants were used in this study. Activity of rubisco and rubisco activase was determined by 6 denaturants using reaction mixture of measurement of rubisco and rubisco activase activity, respectively. Results were calculated presuming the activity of denaturants untreated control as $100 \%$.

\section{Statistical analysis}

Data were analyzed using a one-way analysis of variance (ANOVA) accompanied with Tukey's tests and Student's t-test (SPSS for Windows, Ver. 21). Standard error between replicates was also calculated.

\section{Results}

\section{Effects of ESA on growth of tobacco plant}

To measure total fresh weights to compare growth of tobacco depending on ESA concentration after in vitro culture in MS media containing no ESA and MS media containing ESA from $10^{-6} \mathrm{mM}$ to $10 \mathrm{mM}$ of ESA, it was found that total fresh weight was $9.2 \mathrm{~g}$ in control, $13 \mathrm{~g}$ at $10^{-6} \mathrm{mM}, 13 \mathrm{~g}$ at $10^{-5} \mathrm{mM}, 17 \mathrm{~g}$ at $10^{-4} \mathrm{mM}, 11 \mathrm{~g}$ at $10^{-3} \mathrm{mM}, 8 \mathrm{~g}$ at $10^{-2}$ $\mathrm{mM}, 8 \mathrm{~g}$ at $10^{-1} \mathrm{mM}, 4.2 \mathrm{~g}$ at $1 \mathrm{mM}$, and $2.76 \mathrm{~g}$ at $10 \mathrm{mM}$. Thus it was suggested that the plants had the highest value

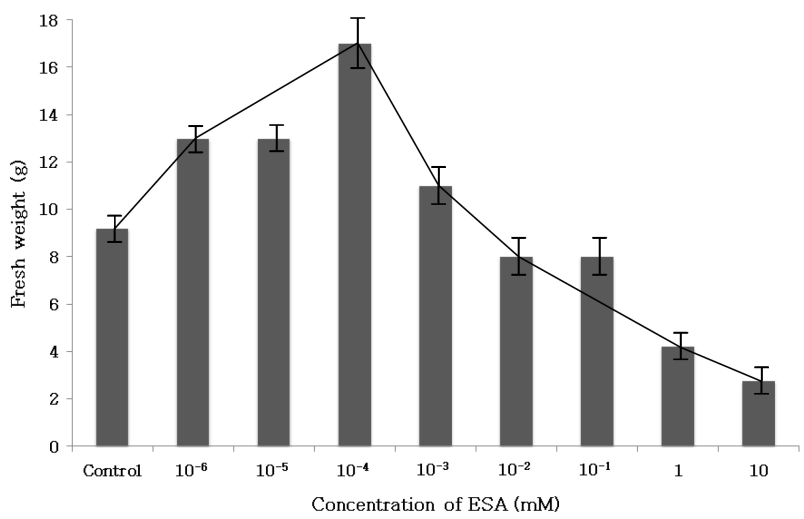

Fig. 1. The fresh weight of tobacco plant cultured on MS medium containing various concentrations of ESA for 10 weeks.

of fresh weight and its weight decreased when the ESA concentration increases more over $10^{-2} \mathrm{mM}$. The $10^{-4} \mathrm{mM}$ ESA obtained from this result was used as optimal concentration (Fig. 1).

\section{Influences of $\mathrm{Cd}$ and $\mathrm{ESA}$ on growth of tobacco plant}

Effects of ESA and Cd on tobacco growth were studied through in vitro culture of tobacco in MS medium. The growth of ESA treated group was the best and the growth of $\mathrm{Cd}$ treated group was the lowest. The control and the mixed group showed similar growth results. As results of comparing growth between the $\mathrm{Cd}$ treated group and control, it was found that the growth of $\mathrm{Cd}$ treated group was lower and the growth of ESA treated group was higher in comparison of growth between the control and ESA treated group. In addition in comparing growth between the $\mathrm{Cd}$ treated group and the $\mathrm{Cd}$ and ESA mixed group, the $\mathrm{Cd}$ treated group showed lower growth. As results of comparing growth among the $\mathrm{Cd}$ treated group, the ESA treated group, and the $\mathrm{Cd}$ and ESA mixed group, it was identified that ESA recovered growth inhibition by Cd (Fig. 2 upper).

In order to confirm the above results, total fresh weights were measured in tobacco. It was identified that the results were in same trend to the results of Fig. 2 upper as 10.495 $\mathrm{g}$ of the control, $6.195 \mathrm{~g}$ of the $\mathrm{Cd}$ treated group, $15.538 \mathrm{~g}$ of the ESA treated group, and $10.495 \mathrm{~g}$ of the $\mathrm{Cd}$ and ESA mixed group (Fig. 2 lower).

\section{Influences of $\mathrm{Cd}$ and ESA on content and activity of rubisco}

It was found that the content of rubisco was $0.05 \mathrm{mg} / \mathrm{ml}$ 


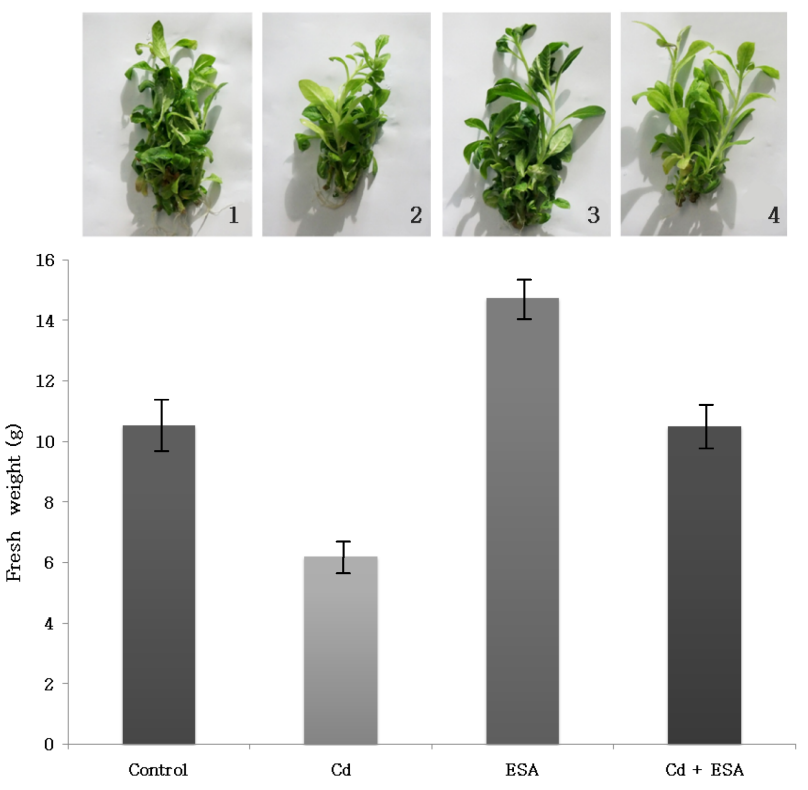

Fig. 2. Effect of $\mathrm{Cd}$ and ESA on growth of tobacco plants. Total fresh weight of tobacco plant was determined. in vitrc culture of tobacco was performed on MS medium without Cd + ESA (control, 1), with Cd (2), $10^{4} \mathrm{mM} \mathrm{ESA}$ (3), and Cd + ESA (4), respectively, for 12 weeks.

in the control, $0.01 \mathrm{mg} / \mathrm{ml}$ in the $\mathrm{Cd}$ treated group, 0.02 $\mathrm{mg} / \mathrm{ml}$ in the ESA treated group, and $0.02 \mathrm{mg} / \mathrm{ml}$ in the $\mathrm{Cd}$ and ESA mixed group, so the content of the control was the best and the $\mathrm{Cd}$ treated group showed the lowest content. The ESA treated group and the mixed group showed same content. As results of comparing the content between the $\mathrm{Cd}$ treated group and the control, it was found that the content of $\mathrm{Cd}$ treated group was lower and the ESA treated group showed lower content in comparison of growth between the control and the ESA treated group. In addition in comparing content between $\mathrm{Cd}$ treated group and Cd and ESA mixed group, the Cd and ESA mixed group showed higher content. As results of comparing content among the Cd treated group, the ESA treated group, and the Cd and ESA mixed group, it was identified that ESA recovered growth inhibition by $\mathrm{Cd}$ but did not reach the level of control (Fig. 3).

It was found that the activity of rubisco was $0.280 \mathrm{unit} / \mathrm{ml}$ in the control, $0.274 \mathrm{unit} / \mathrm{ml}$ in the $\mathrm{Cd}$ treated group, 0.304 unit $/ \mathrm{ml}$ in the ESA treated group, and $0.280 \mathrm{unit} / \mathrm{ml}$ in the $\mathrm{Cd}$ and ESA mixed group, so the activity of the ESA treated group was the best and the $\mathrm{Cd}$ treated group showed the lowest activity. The ESA treated group and the mixed group showed same activity. The activity of control and $\mathrm{Cd}$ and ESA mixed group was same. In comparing the activity be-

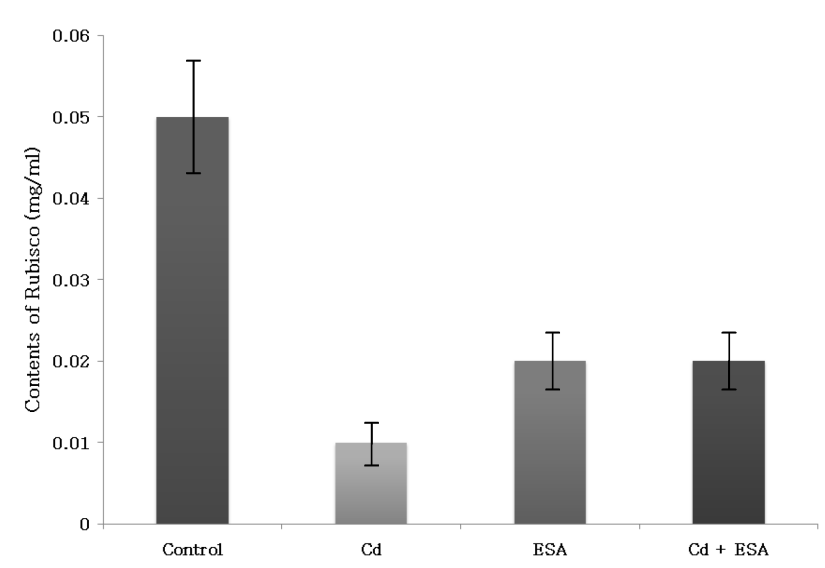

Fig. 3. Effect of $\mathrm{Cd}$ and ESA on content of rubisco in tobacco leaves. Plants were cultured on MS medium without $\mathrm{Cd}$ + ESA (control), with Cd, $10^{4} \mathrm{mM} \mathrm{ESA}$, and Cd + ESA, respectively.

tween the $\mathrm{Cd}$ treated group and the control, the $\mathrm{Cd}$ treated group showed lower activity and in comparing activity between the ESA treated group and the control, the EST treated group sowed higher activity. In addition, in comparing activity between the ESA treated group and the Cd and ESA mixed group, it was found that the ESA treated group showed higher growth. As results of comparing the activity among the $\mathrm{Cd}$ treated group, the ESA treated group, and the Cd and ESA mixed group, it was identified that ESA recovered activity inhibition by $\mathrm{Cd}$ up to the level of control (Fig. 4).

Influences of $\mathrm{Cd}$ and ESA on content and activity of rubisco activase

It was suggested that the content of rubisco activase was

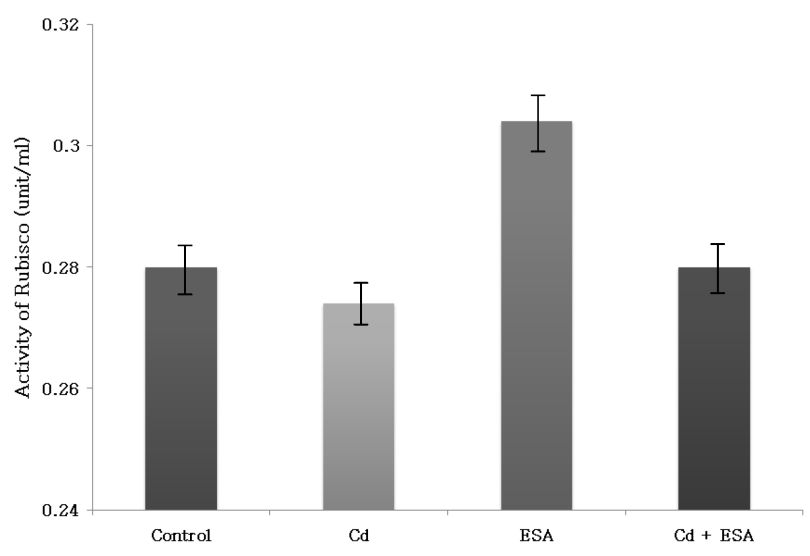

Fig. 4. Effect of Cd and ESA on activity of rubisco in tobacco leaves. Plants were cultured on MS medium without $\mathrm{Cd}$ + ESA (control), with Cd, $10^{-4} \mathrm{mM} \mathrm{ESA}$ and Cd + ESA, respectively. 
greater in order of ESA $>$ control $>\mathrm{Cd}+\mathrm{ESA}>\mathrm{Cd}$ treated group, as $0.013 \mathrm{mg} / \mathrm{ml}$ in the control, $0.010 \mathrm{mg} / \mathrm{ml}$ in the $\mathrm{Cd}$ treated group, $0.015 \mathrm{mg} / \mathrm{ml}$ in the ESA treated group, and $0.011 \mathrm{mg} / \mathrm{ml}$ in the Cd and ESA mixed group. As results of comparing the content between the $\mathrm{Cd}$ treated group and the control, it was found that the content of $\mathrm{Cd}$ treated group was lower and the ESA treated group showed higher content in comparison of content between the control and the ESA treated group. In addition, in comparing the content between the $\mathrm{Cd}$ treated group and the $\mathrm{Cd}$ and ESA mixed group, the $\mathrm{Cd}$ and ESA mixed group showed higher content. As results of comparing content among the $\mathrm{Cd}$ treated group, the ESA treated group, and the Cd and ESA mixed group, it was identified that ESA recovered growth inhibition by $\mathrm{Cd}$, but did not reach the level of control (Fig. $5)$.

It was suggested that the activity of rubisco activase was greater in order of control $>\mathrm{ESA}>\mathrm{Cd}+\mathrm{ESA}>\mathrm{Cd}$ treated group, as $0.278 \mathrm{unit} / \mathrm{ml}$ in the control, $0.250 \mathrm{unit} / \mathrm{ml}$ in the $\mathrm{Cd}$ treated group, $0.269 \mathrm{unit} / \mathrm{ml}$ in the ESA treated group, and $0.265 \mathrm{unit} / \mathrm{ml}$ in the Cd and ESA mixed group. In comparing the activity between the $\mathrm{Cd}$ treated group and the control group, the $\mathrm{Cd}$ treated group showed lower activity and in comparing the activity between the ESA treated group and the control, the ESA treated group showed lower activity. In addition, when comparing the activity between the ESA treated group and the Cd and ESA mixed group, it was found that the ESA treated group showed higher activity. As results of comparing the activity among the $\mathrm{Cd}$ treated group, the ESA treated group, and the Cd and ESA

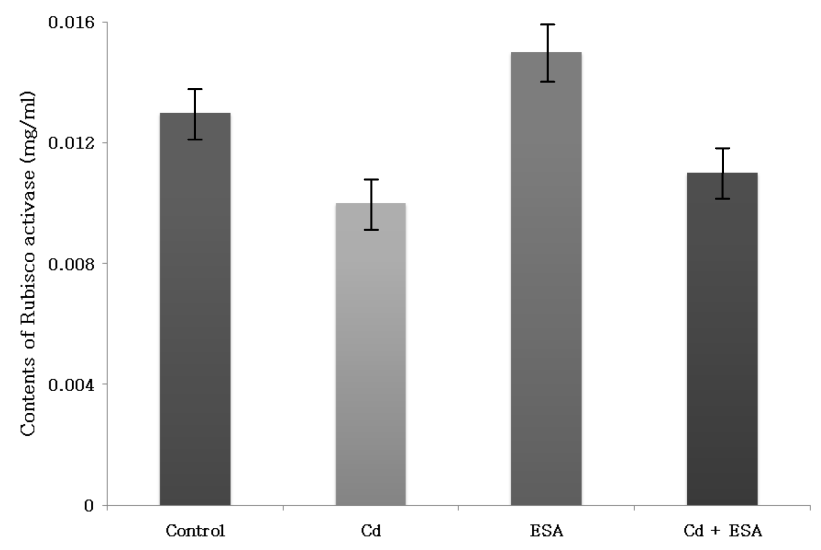

Fig. 5. Effect of Cd and ESA on content of rubisco activase in tobacco leaves. Plants were cultured on MS medium without $\mathrm{Cd}+\mathrm{ESA}$ (control), with $\mathrm{Cd}, 10^{4} \mathrm{mM}$ ESA, and $\mathrm{Cd}+\mathrm{ESA}$, respectively. mixed group, it was identified that ESA recovered growth inhibition by $\mathrm{Cd}$, but did not reach the level of control (Fig. 6).

\section{Influences of denaturants on rubisco activity}

To determine the effects of denaturant on the activity of rubisco, it was found that for control, the activity of rubisco was $83 \%$ in L-cysteine, $79 \%$ in $\beta$-mercaptoethanol, $79 \%$ in EDTA, $75 \%$ in urea, $83 \%$ in thiourea, and $100 \%$ in guanidine- $\mathrm{HCl}$; for the $\mathrm{Cd}$ treated group, it was $46 \%$ in L-cysteine, $38 \%$ in $\beta$-mercaptoethanol, $46 \%$ in EDTA, $50 \%$ in urea, $46 \%$ in thiourea, and $50 \%$ in guanidine- $\mathrm{HCl}$; for the ESA treated group, it was $42 \%$ in L-cysteine, $42 \%$ in $\beta$-mercaptoethanol, $46 \%$ in EDTA, $46 \%$ in urea, $46 \%$ in thiourea, and $62 \%$ in guanidine- $\mathrm{HCl}$, and; for the $\mathrm{Cd}$ and ESA mixed group, it was $46 \%$ in L-cysteine, $50 \%$ in $\beta$-mercaptoethanol, $58 \%$ in EDTA, $50 \%$ in urea, $67 \%$ in thiourea, and $54 \%$ in guanidine- $\mathrm{HCl}$. It was suggested that all the 5 types of denaturant inhibited the activity of rubisco in control, the activity of rubisco was inhibited by L-cysteine, urea, thiourea, $\beta$-mercaptoethanol, and EDTA except guanidine-HCl. In the ESA treated group, higher activity was shown than the $\mathrm{Cd}$ treated group in thiourea and $\beta$-mercaptoethanol. In comparing the activity between the $\mathrm{Cd}$ treated group and the $\mathrm{Cd}$ and ESA mixed group, it was found that the Cd and ESA mixed group showed higher activity in the other denaturants except L-cysteine and urea (Table 1). As shown in the above, it was shown that the activity of rubisco by Cd and ESA was inhibited by denaturants and recovery effect of ESA against $\mathrm{Cd}$ was lost by the denaturants.

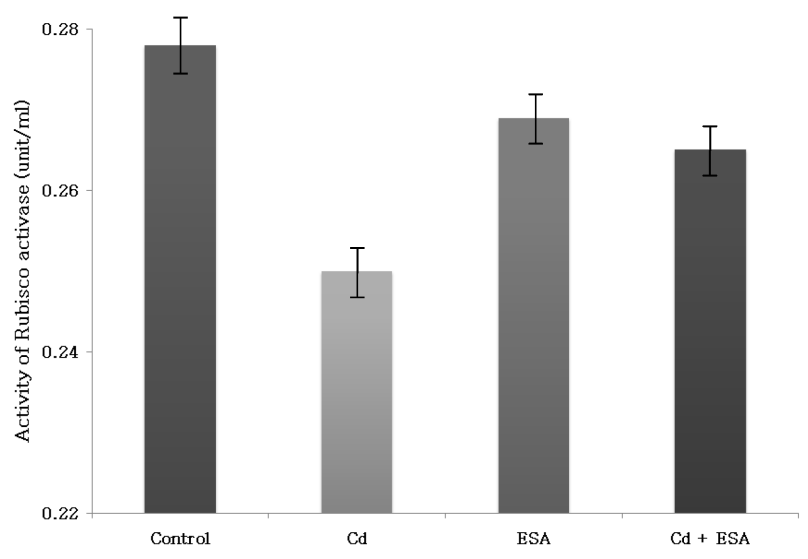

Fig. 6. Effect of Cd and ESA on activity of rubisco activase in tobacco leaves. Plants were cultured on MS medium without Cd + ESA (control), with Cd, $10^{4} \mathrm{mM} \mathrm{ESA}$, and Cd + ESA, respectively. 
Table 1. Effects of denaturants on rubisco activity

\begin{tabular}{lcccc}
\hline \multirow{2}{*}{ Denaturants } & \multicolumn{4}{c}{ Rubisco activity (\%) } \\
\cline { 2 - 5 } & Control $^{1}$ & Cd $^{2}$ & ESA $^{3}$ & Cd+ESA \\
\hline L-Cysteine & 83 & 46 & 42 & 46 \\
3-Mercaptoethanol & 79 & 38 & 42 & 50 \\
EDTA & 79 & 46 & 46 & 58 \\
Urea & 75 & 50 & 46 & 50 \\
Thiourea & 83 & 46 & 62 & 67 \\
Guanidine-HCl & 100 & 50 & 50 & 54 \\
\hline
\end{tabular}

${ }^{1}$ no treated with $\mathrm{Cd}$ and ESA

${ }^{2} 0.2 \mathrm{mM} \mathrm{CdCl}_{2} 2.5 \mathrm{H}_{2} \mathrm{O}$

${ }^{3} 10^{-4} \mathrm{mM}$ ESA

\section{Influences of denaturants on rubisco activase activity}

To investigate the effects of denaturant on the activity of rubisco activase, it was found that for control, the activity of rubisco activase was $100 \%$ in L-cysteine, urea, thiourea, and guanidine- $\mathrm{HCl}$, and $120 \%$ in $\beta$-mercaptoethanol and EDTA; for the Cd treated group, it was $60 \%$ in L-cysteine, $\beta$-mercaptoethanol, EDTA, and urea, 50\% in thiourea, and $40 \%$ in guanidine- $\mathrm{HCl}$; for the ESA treated group, it was $60 \%$ in L-cysteine, EDTA, urea, thiourea, guanidine- $\mathrm{HCl}$, and $40 \%$ in $\beta$-mercaptoethanol, and; for the Cd and ESA mixed group, it was $60 \%$ in L-cysteine, EDTA, urea, thiourea, guanidine- $\mathrm{HCl}$, and $80 \%$ in $\beta$-mercaptoethanol. It was suggested that all the 5 types of denaturant inhibited the activity of rubisco activase and in control, the activity of rubisco activase was inhibited by L-cysteine, urea, thiourea, $\beta$-mercaptoethanol, and EDTA except guanidine- $\mathrm{HCl}$. In the ESA treated group, it was found that while the activity in thiourea and guanidine- $\mathrm{HCl}$ was higher, in $\beta$-mercaptoethanol it was lower than the $\mathrm{Cd}$ treated group. In comparing the activity between the $\mathrm{Cd}$ treated group and the $\mathrm{Cd}$ and ESA mixed group, it was shown that the activity of the $\mathrm{Cd}$ and ESA mixed group was higher in $\beta$-mercaptoethanol and guanidine- $\mathrm{HCl}$ (Table 2). As shown in the above, it was shown that the activity of rubisco activase by Cd and ESA was inhibited by the denaturants and the recovery effect of ESA against Cd was lost by the denaturants.

\section{Discussion}

Growth of plants is affected by chemical factors such as organic and inorganic matters in soil and physical factors such as light and temperature. Among the inorganic matters, heavy metals in soil inhibit growth of plants [11, 33]. In plant, primary metabolites functions in growth and develop-
Table 2. Effects of denaturants on rubisco activase activity

\begin{tabular}{lcccc}
\hline \multirow{2}{*}{ Denaturants } & \multicolumn{4}{c}{ Rubisco activase activity (\%) } \\
\cline { 2 - 5 } & Control $^{1}$ & Cd $^{2}$ & ESA $^{3}$ & Cd+ESA \\
\hline L-Cysteine & 100 & 60 & 60 & 60 \\
B-Mercaptoethanol & 120 & 60 & 40 & 80 \\
EDTA & 120 & 60 & 60 & 60 \\
Urea & 100 & 60 & 60 & 60 \\
Thiourea & 100 & 50 & 60 & 60 \\
Guanidine-HCl & 100 & 40 & 60 & 60 \\
\hline
\end{tabular}

${ }^{1}$ no treated with $\mathrm{Cd}$ and ESA

${ }^{2} 0.2 \mathrm{mM} \mathrm{CdCl}_{2} 2.5 \mathrm{H}_{2} \mathrm{O}$

${ }^{3} 10^{-4} \mathrm{mM}$ ESA

ment of plants as essential substances required for cells and secondary metabolites also have various functions in plant. One of secondary metabolites, SA, acts as a growth regulator, is supposed to be involved in various signal transduction pathways in plants [22]. Although ESA, a derivative of SA, is not synthesized naturally in plant, it can be synthesized chemically.

In order to determine optimal concentration of ESA for growth of tobacco, total fresh weight of tobacco was determined and compared in a range of $10^{-6} \mathrm{mM}-10 \mathrm{mM}$ of ESA. Between $10^{-6} \mathrm{mM}$ of ESA and $10^{-3} \mathrm{mM}$ of ESA, total fresh weight of tobacco was increased with increase of the concentration, but the growth was inhibited at high concentration over $10^{-2} \mathrm{mM}$. The optimal concentration of ESA was $10^{-4} \mathrm{mM}$. Tang et al. [28] reported that SA promoted growth of plant, which was same to the result of this study.

By comparing effects of $\mathrm{Cd}$ and ESA on growth of in vitro culture tobacco, an effect of ESA on the effect of Cd was studied. The growth was the best in the ESA treated group, the lowest in the $\mathrm{Cd}$ treated group, and showed similar results in the control group and the mixed group. The result of the $\mathrm{Cd}$ treated group was lower than that of control, which was resulted from inhibition of growth by $\mathrm{Cd}$. In comparing results between control and the ESA treated group, the ESA treated group showed higher result, which means that ESA promoted the growth of tobacco. These results were consistent with effects of SA on the growth of tobacco [30].

From results of comparison among the $\mathrm{Cd}$ treated group, the ESA treated group, the Cd and ESA mixed group, it was identified that the growth inhibited by $\mathrm{Cd}$ was recovered by ESA, which was considered as a result that ESA reduced the growth inhibition by $\mathrm{Cd}$. From the report that SA mitigated toxic effects of $\mathrm{Cd}$ in plant [7] and the result that SA 
improved the content and the activity of rubisco and rubisco activase inhibited by the Cd [30], it was supposed that ESA would also mitigate the effect of $\mathrm{Cd}$ and this study was performed. The effect of SA on the effect of $\mathrm{Cd}$ was studied by comparing content and activity results of rubisco induced by $\mathrm{Cd}$ and $\mathrm{SA}$.

The content of rubisco was the highest in control and the lowest in the $\mathrm{Cd}$ treated group, and showed similar trends in the ESA treated the Cd and ESA mixed group. In comparing the $\mathrm{Cd}$ treated group, the ESA treated group, and the $\mathrm{Cd}$ and ESA mixed group, it was found that although ESA recovered the inhibition by $\mathrm{Cd}$, the result did not reach the level of control group. The activity of rubisco was the highest in the ESA treated group, the lowest in the Cd treated group, and same in control and the Cd and ESA mixed group. Pankovic et al. [15] reported that high concentration of $\mathrm{Cd}$ inhibited activity of rubisco in sunflower leaves. In comparing the $\mathrm{Cd}$ treated group, the ESA treated group, and the Cd and ESA mixed group, it was found that ESA recovered the inhibition by $\mathrm{Cd}$ up to the level of control. These results show that ESA improves the content and the activity of rubisco.

In order to study if the result of Cd and ESA on rubisco is associated with the rubisco activase, the content and activity of rubisco activase was measured. It was found that the content of rubisco activase was greater in order of $\mathrm{Cd}<\mathrm{Cd}$ + ESA $<$ control $<$ ESA and the activity of rubisco activase was greater in order of $\mathrm{Cd}<\mathrm{Cd}+\mathrm{ESA}<\mathrm{ESA}<$ control. In comparing the $\mathrm{Cd}$ treated group, the ESA treated group, and the Cd and ESA mixed group, it was shown that although ESA recovered the inhibition by $\mathrm{Cd}$, the result did not reach the level of control. These results were same to the results of Wang and Roh [30] that SA improved the content and the activity of rubisco activase inhibited by $\mathrm{Cd}$.

Although when an enzyme is denaturalized, bindings to stabilized tertiary structure of protein are unstabilized and the activity would be lost [5], the activity would be recovered and maintained in removing these factors. In addition it was supposed that the denaturants were related to the activity of rubisco and rubisco activase, so the effects of denaturant were studied. While L-cysteine and $\beta$-mercaptoethanol containing $\mathrm{SH}$ group induces denaturation, degrading disulfide bond, urea, thiourea and guanidine- $\mathrm{HCl}$ are materials forming strong hydrogen bond with protein [27].

We have previously hypothesized that the activity of rubisco and rubisco activase is associated with the denaturant.
In this study, the activity of rubisco was inhibited by all the L-cysteine, $\beta$-mercaptoethanol, EDTA, urea, thiourea and guanidine- $\mathrm{HCl}$ in control group, the activity of rubisco was inhibited by L-cysteine, urea, thiourea, $\beta$-mercaptoethanol, and EDTA except guanidine-HCl. In the ESA treated group, higher activity was shown than the $\mathrm{Cd}$ treated group in thiourea and $\beta$-mercaptoethanol. As results of comparing the activity between the $\mathrm{Cd}$ treated group and the $\mathrm{Cd}$ and ESA mixed group, it was found that the Cd and ESA mixed group showed higher activity in the other denaturants except L-cysteine and urea. Rubisco activity in SA was promoted by L-cysteine and $\beta$-mercaptoethanol, not by urea, thiourea and guanidium- $\mathrm{HCl}$ [30]. Jiang et al. [10] reported that the activity of rubisco decreased more than $50 \%$ and decreased up to $100 \%$ by $0.2 \mathrm{M}$ guanidine- $\mathrm{HCl}$ and $0.4 \mathrm{M}$ guanidine- $\mathrm{HCl}$, respectively.

The activity of rubisco activase was inhibited by all the L-cysteine, $\beta$-mercaptoethanol, EDTA, urea, thiourea and guanidine- $\mathrm{HCl}$ in control group, the activity of rubisco was inhibited by L-cysteine, urea, thiourea, $\beta$-mercaptoethanol, and EDTA except guanidine- $\mathrm{HCl}$. In the ESA treated group, it was found that while the activity in thiourea and guanidine- $\mathrm{HCl}$ was higher, it was lower than the $\mathrm{Cd}$ treated group in $\beta$-mercaptoethanol. In comparing the activity between the $\mathrm{Cd}$ treated group and the $\mathrm{Cd}$ and ESA mixed group, it was shown that the activity of the Cd and ESA mixed group was higher in $\beta$-mercaptoethanol and guanidine- $\mathrm{HCl}$. These are not similar to the results of Wang and Roh [30], where all of denaturants did not affect the activity of rubisco activase. Son et al. [25] reported that the activity of rubisco activase decreased by six dentaurants, lower than that in control, and in most cases, the activity decreased most by EDTA and guanidine- $\mathrm{HCl}$, and decreased least by L-cysteine and urea.

In conclusion, it was identified that ESA inhibited the content of rubisco and promoted its activity, whereas promoted the content of rubisco activase and inhibited its activity. In addition, the content and activity of rubisco and rubisco activase inhibited by $\mathrm{Cd}$ were recovered by ESA. The denaturants inhibited the activity of rubisco and rubisco activase by Cd and ESA and recovery of the activity by ESA was lost by the denaturants.

\section{Acknowledgment}

The research was supported by the Bisa Research Grant 
of Keimyung University in 2012.

\section{References}

1. Amin, A. M., Wang, L., Wang, J., Yu, H., Huo, J., Gao, J. and Xiao, A. 2009. Recent research progress in the synthesis of polyphosphazene and their applications. Des Monop Polym 12, 357-375.

2. Amin, A. M., Wang, L., Wang, H., Yu, J., Gao, C., Li, J., Huo, W., Amer, W. A., Yan, G. and Ma, L. 2010. Synthesis and characterization of poly [bis (ethyl salicylate) phosphazenes] and poly [bis (ethyl salicylate diethylamino) phosphazenes] and their hydrolytic degradation. Polym Plast Tech Eng 49, 1399-1405.

3. Bishop, M. B. and Bishop, C. B. 1987. Photosynthesis and carbon dioxide fixation. J Chem Ed 64, 302-305.

4. Bradford, M. M. 1976. A rapid and sensitive method for the quantification of microgram quantities of protein utilizing the principle of protein-dye binding. Anal Biochem 72, 248-254.

5. Camacho, C. J. and Thirumalai, D. 1996. Denaturants can accelerate folding rates in a class of globular proteins. Protein Sci 5, 1826-1832.

6. Chen, X. L. 2009. Determination of ethyl salicylate anti-bacterial activity in vitro. J Anhui Agri 37, 455-456.

7. Drazic, G. and Mihailovic, N. 2005. Modification of cadmium toxicity in soybean seedlings by salicylic acid. Plant Sci 168, 511-517.

8. Ellis, R. J. 1979. The most abundant protein in the world. Trends Biochem Sci 4, $241-244$.

9. Han, Y., Chen, G. and Wang, Z. 2000. The progresses of studies on rubisco activase. Chin Bulletin Bot 17, 306-311.

10. Jiang, R. F., Wang, Z. X. and Xu, G. J. 1997. Substrate induced reactivation of spinach ribulose-1,5-bisphosphate carboxylase/oxygenase denatured by low concentrations of guanidine hydrochloride. Biochim Biophys Acta 1343, 95-101.

11. Kneer, R. and Zenk, M. H. 1991. Phytochelatins protect plant enzymes from heavy metal poisoning. Phytochem 31, 26632667.

12. Li, H. X., Wang, Z. M. and Zeng, H. L. 2010. The research progresses in rubisco activase in plant. Bulletin Plant Physiol 46, 1092-1100.

13. Li, R., Xie, W. and Wang, X. 2009. Synthesis and application of ethyl salicylate. Liaon Chem Indust 38, 831-833.

14. Murashige, T. and Skoog, F. 1962. A revised medium for rapid growth and bioassay with tobacco tissue cultures. Physiol Plant 15, 473-497.

15. Pankovic, D., Plesnicar, M., Arsenijevic Maksimovic, I., Petrovic, N., Sakac, Z. and Kastori, R. 2000. Effect of nitrogen nutrition on photosynthesis in $\mathrm{Cd}$ treated sunflower plants. J Ann Bot 86, 841-847.

16. Portis, A. R. Jr. 2003. Rubisco activase: Rubisco's catalytic chaperone. Photosynth Res 75, 11-27.

17. Prasad, M. N. V. 1995. Cadmium toxity and tolerance in vascular plants. Environ Exp Bot 35, 525-545.

18. Racker, E. 1962. Ribulose diphosphate carboxylase from spi- nach leaves. Methods Enzymol 5, 266-270.

19. Robinson, S. P. and Portis, A. R. Jr. 1989. Adenosine triphosphate hydrolysis by purified rubisco activase. Arch Biochem Biophy 268, 93-99.

20. Roh, K. S. and Chin, H. S. 2005. Cadmium toxicity and calcium effect on growth and photosynthesis of tobacco. J Life Sci $15,453-460$.

21. Salvucci, M. E. and Ogren, W. L. 1996. The mechanism of rubisco activase: insights from studies of the properties and structure of the enzyme. Photosynth Res 47, 1-11.

22. Shulaev, V., Silverman, P. and Raskin, I. 1997. Airborne signaling by methyl salicylate in plant pathogen resistance. Nature 385, 718-721.

23. Schmitt, G., Nguyen, D. A., Poupelin, J. P., Vebrel, J. and Lande, B. 1984. A new and mild synthesis of substituted salicylic acids. Synth 9, 758-765.

24. Siedlecka, A. and Krupa, Z. 1996. Interaction between cadmium and iron and its effects on photosynthetic capacity of primary leaves of Phaseolus vulgaris. Plant Physiol Biochem 34, 833-841.

25. Son, J. A., Damodaran, P. N. and Roh, K. S. 2014. Influence of exogenous application of glutathione on rubisco and rubisco activase in heavy metal-stressed tobacco plant grown in vitro. Saudi J Biol Sci 21, 89-97.

26. Spreitzer, R. J. and Salvucci, M. E. 2002. Rubisco: structure, regulatory interactions and possibilities for a better enzyme. Ann Reviews Plant Bio 53, 449-475.

27. Stiborova, M. 1988. $\mathrm{Cd}^{2+}$ ions affect the quaternary structure of ribulose- 1,5-bisphoshate carboxylase from barley leaves. Biochemia Physiol Planzen 183, 371-378.

28. Tang, J., Hou, L. X., Che, Y. M. and Liu, X. 2007. The effects of exogenous salicylic acid and nitric oxide on maize seed germination and the activity of amylase. Anhui Agri Sci Bull $19,40-42$.

29. Van Bruwaene, R., Kirchmann, R. and Inpens, R. 1984. Cadmium contamination in agriculture and zoo technology. Experientia 40, 43-52.

30. Wang, Y. S. and Roh, K. S. 2012. The reverse effect of salicylic acid on $\mathrm{Cd}$ induced growth, chlorophyll, and rubisco/rubisco activase in tobacco. J Life Sci 22, 778-787.

31. Wang, Z. Y., Snyder, G. W., Esau, B. D., Portis, A. R. Jr. and Ogren, W. L. 1992. Species-dependent variation in the interaction of substrate-bound ribulose 1,5-bisphosphate carboxylase/oxygenase (rubisco) and rubisco activase. Plant Physiol 100, 1858-1862.

32. Wishnick, M. and Lane, M. D. 1971. Ribulose disphosphate carboxylase from spinach leaves. Methods Enzymol 23, 570-577.

33. Zhang, G. and Taylor, G. J. 1989. Kinetics of aluminum uptake by excised roots of aluminum-tolerant and aluminum-sensitive cultivars of Tritcum aestivum L. Plant Physiol 91, 1094-1099.

34. Zhang, N., Schürmann, P. and Portis, A. R. Jr. 2001. Characterization of the regulatory function of the $46-\mathrm{kD}$ isoform of rubisco activase from Arabidopsis. Photosynth Res 68, 29-37. 
초록 : 카드뮴(Cd) 하에서 기내 배양된 담배의 생장과 Rubisco/Rubisco Activase에 대한 Ethylsalicylic acid의 영향 분석

노광수 ${ }^{*}$ 최추결

(계명대학교 생물학과)

카드뭄 $(\mathrm{Cd})$ 에 의해 유도되는 담배의 생장과 rubisco/rubisco activase에 미치는 ESA (ethylsalicylic acid)의 효과 및 이에 대한 변성제의 효과를 연구하였다. 담배기내 배양에 대한 ESA의 최적 농도를 찾기 위해, $10^{-6}-10 \mathrm{mM} \mathrm{ESA}$ 를 처리 하여 배양시킨 결과, $10^{-4} \mathrm{mM} \mathrm{ESA}$ 에서 생장이 가장 높게 나타났다. 최적농도인 $10^{-4} \mathrm{mM} \mathrm{ESA}$ 와 $0.2 \mathrm{mM} \mathrm{CdCl}$. $2.5 \mathrm{H}_{2} \mathrm{O}$ 를 사용하여, 대조구, $\mathrm{Cd}$ 처리구, $\mathrm{ESA}$ 처리구 및 $\mathrm{Cd}$ 와 $\mathrm{ESA}$ 혼합구에서의 담배의 생장을 측정한 결과, $\mathrm{ESA}$ 처리 구의 생장이 가장 좋았으며, $\mathrm{Cd}$ 처리구의 생장이 가장 저조하였다. Rubisco/rubisco activase의 함량과 활성을 측정한 결과, 두 가지의 함량과 활성 모두 Cd 처리구가 가장 낮았으며, ESA 처리구에서는 Rubisco와 rubisco activase의 함량이 감소되었고, 활성은 증가하였다. Guanidine- $\mathrm{HCl}$ 처리를 제외한 L-cysteine, urea, thiourea, $\beta$-mercaptoethanol, EDTA에 의해 rubisco의 활성이 억제되었으며, L-cysteine, urea, thiourea, guanidine- $\mathrm{HCl}$ 처리구에서는 rubisco activase 활성이 변화가 없었으나, $\beta$-mercaptoethanol과 EDTA는 활성을 증가시키는 것으로 나타났다. 결론적으로, ESA는 rubisco의 함 량을 억제시키고 활성은 촉진시키며, rubisco activase의 함량은 촉진시키고 활성은 억제시켰다. 또한 $\mathrm{Cd}$ 에 의해 저해된 rubisco와 rubisco activase의 활성이 변성제에 의해 저해되었으며, $\mathrm{Cd}$ 에 의해 저해된 $\mathrm{ESA}$ 의 회복이 변성제에 의하여 상실되었다. 